\title{
Frictional energy patterns related to the temperature increases due to intraplate seismicity, southern Norway, 2000-2019 catalogue
}

Claudia Pavez ${ }^{1}$, Rodrigo Estay ${ }^{2}$, Marco Brönner ${ }^{1}$, Adrián Ortiz ${ }^{3}$, Flavio Debarbieri² Juan Patricio Ibañez ${ }^{2} \&$ Luis Guzmán ${ }^{4}$

${ }^{1}$ Norges Geologiske Unders $\varnothing$ kelse, Postbox 6315, Torgarden, 7491, Trondheim, Norway.

2 Department of Metallurgical and Materials Engineering, Universidad Técnica Federico Santa María. Avenida España 1680, Valparaíso, Chile.

${ }^{3}$ Department of Chemical and Environmental Engineering, Universidad Técnica Federico Santa María. Avenida España 1680, Valparaíso, Chile.

${ }^{4}$ Department of Mechanical Engineering, Universidad Técnica Federico Santa María. Avenida España 1680, Valparaíso, Chile.

E-mail corresponding author (Claudia Pavez): claudia.pavez@ngu.no

Low-magnitude seismic events $(0 \leq \mathrm{Mw} \leq 3.8)$ recorded in southern Norway during the period 20002019 were used to calculate the sudden co-seismic temperature increases using a simple stress-drop model. The maximum temperature increase associated with an $\mathrm{Mw}=3.5$ earthquake was $\sim 122^{\circ} \mathrm{C}$. Simultaneously, we added 13 historical earthquakes to our study data, which occurred between 1657 and 1989. Here, the maximum temperature rise was $\sim 560^{\circ} \mathrm{C}$ for an $\mathrm{Mw}=5.6$ event. The temperature values were analysed to derive local thermo-mechanical effects, such as thermal fracturing, frictional drop and the possible formation of cataclasites and pseudotachylites. Using the Kanamori's equations, we estimated the thermal energy released by individual events and in 2D and 3D cumulative patterns. To identify possible correlations between frictional energy, seismicity distribution and regional geology, the results were spatially correlated with a lineament zone located along the southwestern coastline and a heat flux map. Areas with high thermal energy values seem to be spatially linked with zones that exhibit a high density of lineaments and high heat flux located along the whole of the southwestern Norwegian coast.

\section{Summary of the parameters}

\author{
C: specific heat $\left(\mathrm{J} / \mathrm{Kg}^{\circ} \mathrm{C}\right)$ \\ $\mathrm{C}_{\mathrm{s}}$ : fault dimension constant \\ D: displacement offset $(\mathrm{m})$ \\ $\mathbf{E}_{\mathrm{G}}$ : fracture energy $(\mathrm{J})$ \\ $E_{H}$ : frictional energy $(J)$ \\ $\mathbf{E}_{\mathrm{R}}$ : radiated energy $(\mathrm{J})$
}

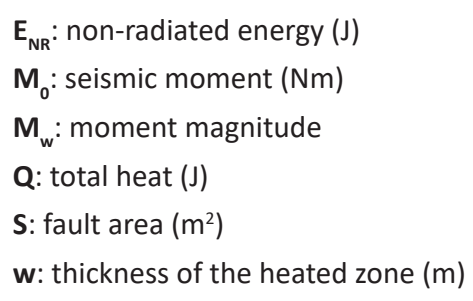

\author{
$\mu$ : rigidity $\left(\mathrm{N} / \mathrm{m}^{2}\right)$ \\ p: density $\left(\mathrm{kg} / \mathrm{m}^{3}\right)$ \\ $\sigma_{0}$ : initial stress (bar) \\ $\sigma_{1}:$ final stress (bar) \\ $\sigma_{\mathrm{f}}$ : frictional stress (bar) \\ $\Delta \sigma_{\mathrm{s}}=\sigma_{0}-\sigma_{1}$ : static stress drop (bar)
}




\section{Introduction}

Earthquake controlled thermal processes have been studied for several decades (Fredrich \& Wong, 1986; Kanamori et al., 1998; Kanamori \& Heaton, 2000; Abercrombie \& Rice, 2005; Aubry et al., 2018). Over the last years, the scientific community has been given special attention to the co-seismic temperature increases and the related thermal energy (Rice, 2006; Beeler et al., 2008; Goldsby \& Tullis, 2011; Hayward et al., 2016; Nielsen et al., 2016; Passelègue et al., 2016; Aubry et al., 2018). Fault weakening resulting from these thermo-mechanical processes has an important effect in several seismological aspects. For example, the spatial distribution of seismicity, the quantification of the frictional-derived thermal energy during sliding (Passelègue et al., 2016; Aubry et al., 2018), and the change in the frictional properties of natural fault rocks due to temperature increases have essential academic and industrial implications (for example, for $\mathrm{CO}_{2}$ storage see Pluymakers et al., 2014 and references therein). However, due to the limited resolution of current seismic methods, frictional heating processes are still impossible to observe directly from seismological data. To understand the generation and effects of frictional energy, analyses of synthetic and recorded seismicity (Kanamori \& Anderson, 1975; Kanamori \& Heaton, 2000), together with laboratory studies and numerical modelling, are necessary (Passelègue et al., 2016; Aubry et al., 2018; Uslar et al., 2020).

Even though seismic energy extraction is currently unlikely, the sudden temperature increase during the co-seismic period of an earthquake and the related cumulative effect of frictional energy can be useful in exposing new associations between microscopic and macroscopic physics of earthquakes as well as with geological regional mechanisms. For example, depending on the earthquake magnitude, the thermal energy processes and the consequent temperature rise during faulting can triggeraseries of processeslikelocalfrictionalmelting(Sibson, 1977), micro-fracturing and variationsinfluid injection (Kanamori \& Heaton, 2000), fluid pressurisation (Mase \& Smith, 1987), and acoustic fluidisation (Melosh, 1996). In the same way, the macroscopic seismic source parameters such as $M_{0}$ and $E_{H}$ can be related to observations of rocks produced by frictional melting or to the presence of fluids (Kanamori \& Heaton, 2000).

During an earthquake, the potential energy is transferred into elastic wave energy and non-radiated energy, $E_{R}$ and $E_{N R}$, respectively (Fig. $1 \mathrm{~A}$ ). The non-radiated energy is here composed by $E_{G}$ and $E_{H}$, where $E_{G}$ is the fracture energy required to mechanically weaken the fault, and $E_{H}$ the energy dissipated locally by frictional heating in the fault core (Kanamori \& Heaton, 2000). The frictional energy calculation involves the estimation of the local temperature rise produced in a very narrow zone around the fault plane (Kanamori \& Heaton, 2000; Di Toro et al., 2006; Passelègue et al., 2016) (see Fig. 1B). This sudden heating produced during the co-seismic slip can cause rock weakening and thermally-related induced fracturing by decreasing friction (Byerlee, 1976; Di Toro et al., 2011; Passelègue et al., 2016). However, all these effects are not visible in seismograms, and most of the conclusions regarding the topic have only theoretical or experimental support (Kanamori \& Heaton, 2000; Kanamori \& Rivera, 2006; Di Toro et al., 2011; Passelègue et al., 2016; Aubry et al., 2018).

Considering the previous terms, the energy budget during a rupture propagation corresponds to the sum of $E_{R}, E_{G}$ and $E_{H}$ (Knopoff, 1958). This total energy is related to the fault parameters as well as to the stresses along the fault plane, the shear stress and the stress drop during the motion, which can be estimated directly from seismograms. The stress drop between the initial and the final stresses $\left(\sigma_{0}\right.$ to $\sigma_{1}$ ) is linked to the states before and after the earthquake: $\Delta \sigma_{s}$ represents this difference, which is called static stress-drop. In the same way, during sliding, the stress is equal to the frictional stress, $\sigma_{f}(u)$, which is in general varying during faulting. However, in the simplest model the frictional stress is constant, defined as the average of the frictional stress during the motion (Kanamori, 2001). The energy partition and the stress-drop process are visualised in the diagram shown in Fig. 1A. 


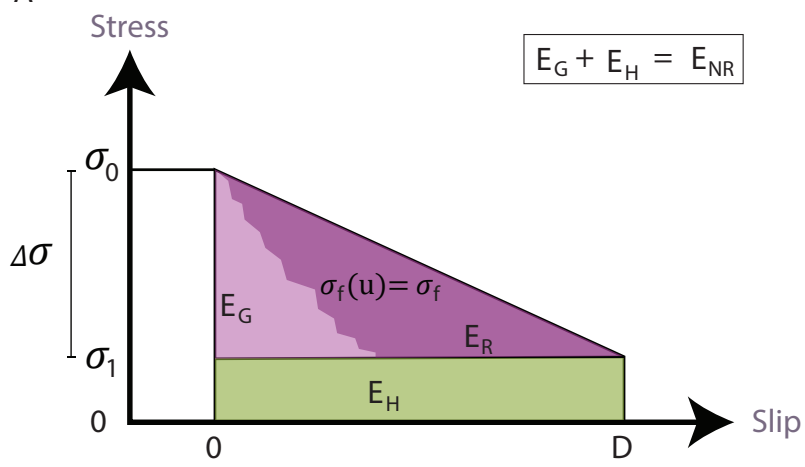

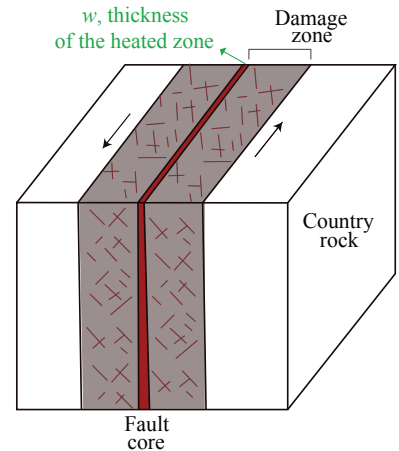

Figure 1. (A) Schematic model of simple stress release for an earthquake. Light purple, purple and green sections correspond to the fracture (EG), radiated (ER) and thermal energy $(E H)$, respectively. $\sigma_{f}(u)=\sigma_{f}$ is defined as the average friction where $u$ is the slip on the fault plane. $D$ in the slip axis corresponds to the displacement offset. Stress-drop behaviour can be inferred from the illustration (modified from Kanamori \& Heaton, 2000). (B) Schematic fault model showing the thickness, henceforth $w$, of the heated zone.

In this paper, we calculate the temperature increases produced by local events from southern Norway in the period 2000-2019. We apply the Kanamori's temperature equations, (Kanamori \& Heaton, 2000), and a simple slip-weakening stress-release model which avoids considering frictional stress variations during the motion. The temperature values allow us to describe some of the thermo-mechanical phenomena related to the low-magnitude local seismicity and the high-magnitude historical events. Additionally, we estimate the maximum total amount of thermal energy produced by the earthquakes considering a temporal step of one year and the hypothetical total frictional energy throughout the entire study period. The results are utilised to develop a comprehensive analysis about the correlations between the spatial behaviour of local seismicity and the effects of heating and cumulative energy in the regional geology. As a primary goal, this study attempts to be the first step to understand the potential regional effects of co-seismic heating produced by the seismicity in southern Norway.

So far, thermal energy estimation can only be used for comparative analyses. Technical and theoretical issues - for example, the unpredictability of seismic events - still make it difficult to overcome all these challenges. Currently, just a few groups worldwide are working on imaging frictional heating processes during laboratory earthquakes and measuring the generated temperatures (Passelegue et al., 2016; Aubry et al., 2018), which means at least that acquiring experimentally-derived empirical values should just be a matter of time.

\section{Seismological setting for southern Norway}

Whilst seismicity in Norway is the highest in northern Europe, the magnitude of seismic events is low to intermediate, and strictly intraplate, both onshore and offshore at the passive continental margin (Bungum et al., 2000; Olesen et al., 2013b). Seismicity is mainly located in the upper $20 \mathrm{~km}$ of the crust and presents a cumulative recurrence relationship that indicates the occurrence of earthquakes equal or above $M_{w}=5.0$ every 8-9 years and even bigger events of $M_{w}=6.0$ every 90-100 years (Olesen et al., 2013b).

It is commonly accepted that seismicity emerges due to a combination of stress-generating mechanisms, from crustal to local scale (Olesen et al., 2013b). Some of the suggested stress-related factors that control these high rates are (i) gravitational potential energy changes produced due to 
topographic loads, (ii) post-glacial isostatic adjustments, (iii) Mid-Atlantic ridge push, (iv) Quaternary glacial erosion and (v) flexural stresses through sedimentation (Olesen et al., 2013b). Additionally, crustal density variations and a spatial coincidence with anomalous low-velocity zones of seismic waves in the upper mantle have been proposed as responsible mechanisms (Bannister et al., 1991; Kolstrup et al., 2015; Hejrani et al., 2017); and finally, a temporal relationship between precipitation and intra-crustal seismicity has also been proposed by Maystrenko et al., $(2018,2020)$. Due to increased deployment of seismic stations in Norway (see http://seismo.geo.uib.no/nnsn/\#/), it is possible to link the above-mentioned stress-generating mechanisms with the regional stress directions through the study of focal mechanisms (Fjeldskaar et al., 2000).

With respect to the spatial location, the highest seismicity levels occur in the rifted continental margin as well as in the strongly faulted regions near to the rifts in the North Sea and in the coastal area of southwestern Norway (Keiding et al., 2015; Norwegian National Seismic Network, 2018). This last area also records high numbers of seismic events on the mainland, in a zone that is highly influenced by the post-Caledonian faults (Bøe et al., 2010). In general, seismicity occurs in pre-existing zones of weakness with an accumulation of stress and low effective shear strength (Olesen et al., 2013b). Deep earthquakesoccurmainly offshore, dominated by reversefaulting and themid-Atlanticridge push, whereas, shallow earthquakes occur onshore where normal faulting is dominant and the horizontal tension is coastperpendicular (Fjeldkaar et al., 2000).

Gabrielsen et al. $(2002,2018)$ defined several fracture zones in Norway. Fracture groups characterised by a high fracture frequency and a common orientation and style are called lineaments. Around southwestern Norway, the Bergen Zone exhibits a population of NNW-SSE-trending lineaments parallel to the coast (Fig. 2). It includes a system of faults with $\mathrm{N}-\mathrm{S}$ trends, and the offshore master faults reflect the presence of a deep zone of weakness (Badley et al., 1984; Gabrielsen, 1986, 1989; Gabrielsen et al., 2002; Færseth et al., 1995) which had been generating seismic activity (Gabrielsen, 1989; Karpuz et al., 1991). Inside the Bergen Zone, the NE-SW-striking Hardangerfjord Shear Zone roots deeply in the crust, truncating the Caledonian basal detachment. Its principal structure is the NWdipping Lærdal-Gjenda Fault Complex. The fault zone exposes mylonites that are cut by cataclasites, both of which are incorporated as clasts in breccia and gouge zones. The palaeomagnetic signature of some of the brittle fault rocks indicates both Permian and Late Jurassic-Early Cretaceous activity (Gabrielsen et al., 2002).

Several heat-flow maps have been published to understand the relationship between heat flux and regional geology (Pascal \& Midttømme, 2006; Slagstad et al., 2009; Pascal, 2009; Pascal et al., 2010, Rudlang, 2010; Olesen et al., 2013a). In southern Norway, particularly, the datasets are sufficiently complete to obtain a reasonable estimation of the heat flux for the North Sea as well as for the Oslo area (Rudlang, 2010; Pascal, 2009; Olesen et al., 2007; Slagstad et al., 2009; Swanberg et al., 1974; Heier \& Grønlie, 1977; Eriksson \& Malmqvist, 1979). Olesen et al. (2013a) collected and interpolated all the available data (see Fig. 2), obtaining as an outcome a $10 \mathrm{~km}$ horizontal resolution heat-flow map. Results show a correlation between the crustal thickness and the deep heat-flow distribution. To the north of the North Sea, the continental margin exhibits high heat-flow values reaching more than $70 \mathrm{~mW} /$ $\mathrm{m}^{2}$, with maximum values of $\sim 100 \mathrm{~mW} / \mathrm{m}^{2}$, coinciding with areas where the influence of the vertical fluid migration could be relevant (Olesen et al., 2013a; Ritter et al., 2004). The same behaviour can be detected close to the Oslo Rift, where heat-flux values are in the range of $70-90 \mathrm{~mW} / \mathrm{m}^{2}$. 


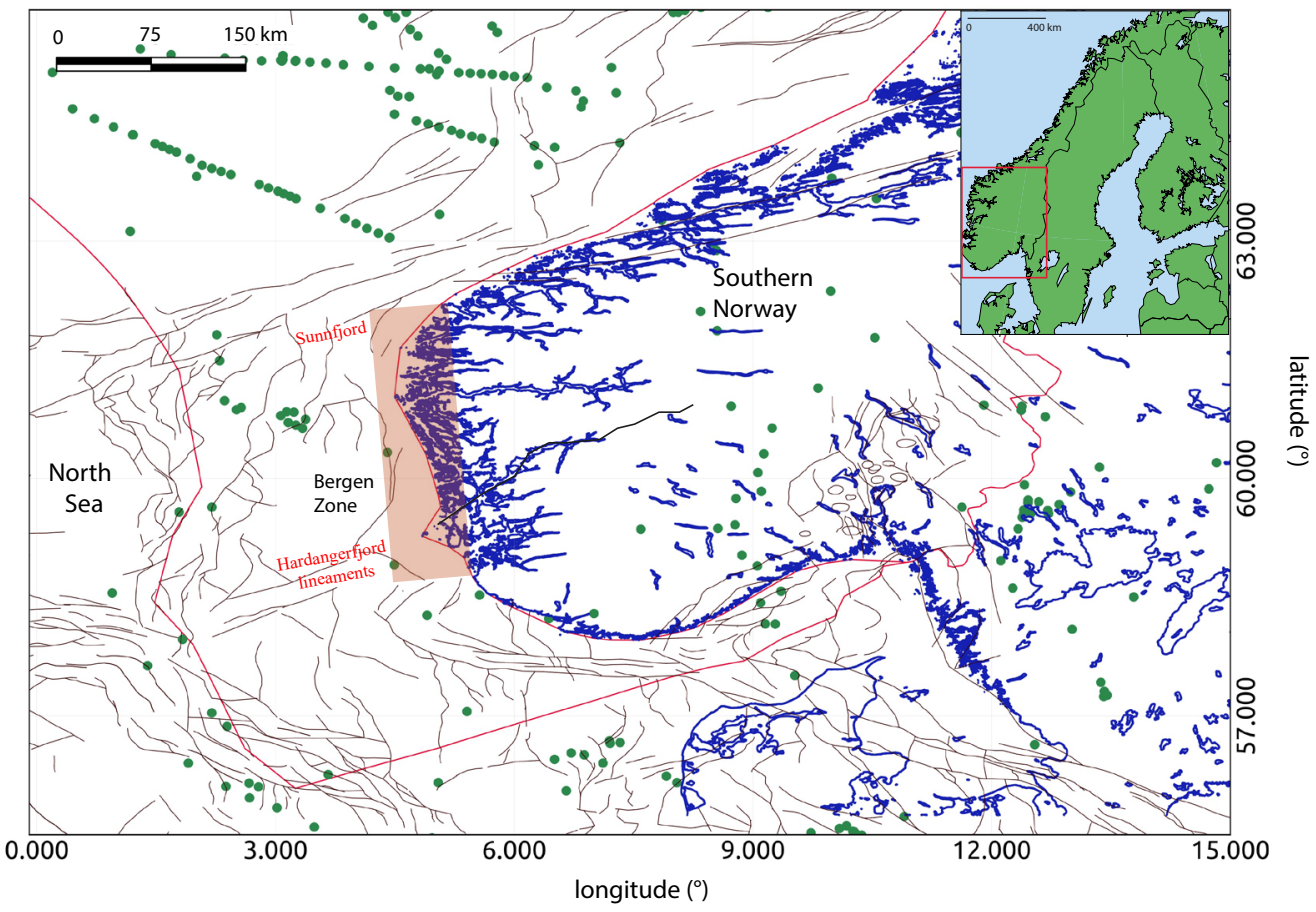

Figure 2. Simplified map of southern Norway and the continental shelf. Green dots represent heat-flow measurements from different authors (Swanberg et al., 1974; Heier \& Grønlie, 1977; Eriksson \& Malmqvist, 1979; Slagstad et al., 2009; Pascal \& Midttømme, 2006; Olesen et al., 2007; Pascal, 2009; Pascal et al., 2010, Rudlang, 2010; Olesen et al., $2013 \mathrm{~b}$ ). The red box is the Bergen Zone as defined by Gabrielsen et al., 2002. A map of the offshore faults can be found in the Norwegian Petroleum Directorate webpage (https://factpages.npd.no/).

\section{Theoretical background}

\section{The Kanamori's equation for frictional energy}

The temperature rise was calculated by considering the gross thermal budget during faulting under a constant frictional stress $\sigma_{\rho}$ as shown in Fig. $1 \mathrm{~A}$ (Kanamori \& Heaton, 2000). Defining S and D as the fault area and the displacement offset, respectively, the total heat, $Q$, generated during faulting can be obtained by

$$
Q=\sigma_{f} D S
$$

If the heat is distributed during seismic faulting within a layer of thickness $w$ around the rupture plane (Fig. 1B), then the average temperature rise could be expressed by

$$
\Delta T=Q / C \rho S w=\left(\sigma_{f} D\right) / C \rho w
$$

where $C$ is the specific heat and $\rho$ is the density. Using a simple circular model (Eshelby, 1957; Kanamori \& Heaton, 2000) in which the static stress drop is $\Delta \sigma_{s}, \mu$ is the rigidity and $M_{0}$ is the seismic moment, it is possible to write the displacement offset, D, as

$$
D=(16 / 7)^{2 / 3} 1 /(\pi \mu) \Delta \sigma_{s}^{2 / 3} M_{0}^{1 / 3}
$$

By combining equations (2) and (3), the temperature rise is then defined by (Kanamori \& Heaton, 2000)

$$
\Delta T=(16 / 7)^{2 / 3} 1 /(\pi \mu C \rho w) \sigma_{f} \Delta \sigma_{S}^{2 / 3} M_{0}^{1 / 3}
$$


where the seismic moment is related to $\mathrm{M}_{w}$ through

$$
\log M_{0}=1.5 M_{w}+9.1
$$

To convert between local $\left(M_{L}\right)$ and moment $\left(M_{w}\right)$ magnitudes, we will use a relationship for small earthquakes $\left(0 \leq M_{L} \leq 3.8\right)$ proposed by Munafo et al., (2016), which is given by

$$
M_{w}=2 / 3 M_{L}+1.15
$$

The estimation of $M_{w}$ in small earthquakes is always a challenging task and its calculation is still under debate (Munafo et al., 2016). Its determination is not simple and in general the definition of regional scales is necessary to correctly relate $M_{L}$ and $M_{w}$ (Ottemöller \& Sargeant, 2013). Moreso, these scales are not always valid for small events (Hanks \& Kanamori, 1979), and several scaling cases show a breakdown for magnitudes under $M_{L} \leq 3.0$ (Bethmann et al., 2011; Deichmann, 2006). In the case of Norway, one local magnitude scale was developed by Alsaker et al. (1991), but its relationship with $M_{w}$ has not been calculated so far.

To calculate the total heat generated during faulting, it is necessary to reuse Equation 1. By considering the static stress-drop calculated from D (Equation 3 ) and the fault dimension through $S$ and $C_{s}($ Vassiliou \& Kanamori, 1982), it can be stated that

$$
\Delta \sigma_{s}=C_{s} \mu D / S^{1 / 2}
$$

If $M_{0}=\mu D S$, then

$$
M_{0}=C_{S} \Delta \sigma_{S} S^{3 / 2}
$$

In general, $C_{S}$ is considered in the order of the unity and determined by the geometry of the fault (Madariaga, 1977). For a circular fault, the minimum value is $C_{s}=0.73$. When the fault is very long and rectangular, $C_{s}$ reaches a maximum value of 1.57 (Keilis-Borok, 1959; Knopoff, 1958; Madariaga, 1977). In all cases $C_{s} \approx 1$, and this value is used for simplicity (Kanamori \& Anderson, 1975). Then, the estimation of the total heat produced by a single event can be obtained from equations (1), (3) and (8).

The possible values of the static stress drop and the frictional stress vary according to the tectonic setting, the type of event and the event magnitude (Abercrombie \& Leary, 1993; Shearer et al., 2006). The choice of the static stress-drop value is, in general, made considering that for most of the earthquakes $\Delta \sigma_{s}$ is below 100 bar. According to the information extracted from 66,000 events, Shearer et al. (2006) found such values in $90 \%$ of the cases. However, the frictional stress values are more complicated to obtain as they depend on energy calculations, and in some cases a wide range of them - between 10 and 10,000 bar - is considered (Kanamori \& Heaton, 2000). Unfortunately, estimations of the frictional and static stress drops are not available for Norway. To solve this issue, we will use the relationships proposed by Kanamori \& Anderson, (1975), which allow us to estimate the frictional stress drop using the initial tectonic stress, $\sigma_{0}$, and the stress drop, $\Delta \sigma_{s}$, through the equations

$$
\begin{gathered}
\sigma_{\mathrm{f}} / \sigma_{0}=1-\varepsilon \\
\sigma_{0}=\Delta \sigma / \varepsilon
\end{gathered}
$$

where $\varepsilon$ corresponds to the fractional stress drop. Considering the above-mentioned and using equations 9 and 10, a good estimation to calculate the maximum frictional energy can be achieved 
using $\Delta \sigma_{s}=100$ bar. According to in situ measurements-overcoring and borehole breakouts-and focal mechanisms, the initial tectonic stress fluctuates between 100 and 150 bar for southern Norway (Fejerskov \& Lindholm, 2000).

\section{Data \& methodology}

The seismic catalogue for southern Norway for the period 2000-2019 (Fig. 3) was downloaded from the Norwegian National Seismic Network webpage http://nnsn.geo.uib.no/nnsn/\#/, which belongs to the University of Bergen. More details about location and processing can be found in its 2018 annual report (Ottemöller et al., 2018; Norwegian National Seismic Network, 2018). The original catalogue consists of 27,477 regional seismic events, for which local magnitude $M_{L}$ was previously calculated through the

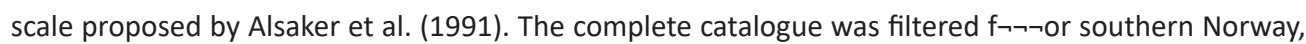
considering the area between $3^{\circ}-12^{\circ} \mathrm{E}$ and $57^{\circ}-64^{\circ} \mathrm{N}$, resulting in a total of 3528 earthquakes (Fig. 4). In this step, just events with $0 \leq M_{L} \leq 3.8$ were selected, following the above-mentioned relationship for small earthquakes proposed by Munafo et al. (2016) (Equation 6). The mean and median for the selected earthquakes are $M_{L}=1.6$ and $M_{L}=1.5$, respectively (see table in Fig. 3 ).

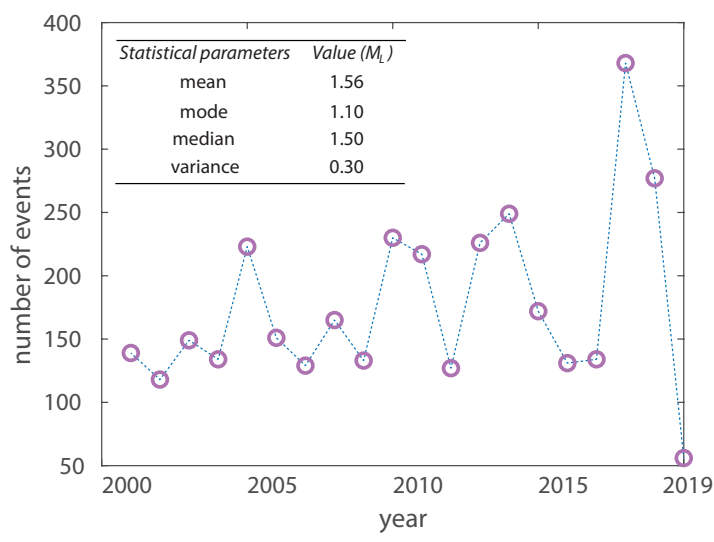

Figure 3. Yearly distribution of regional events for southern Norway during the period 2000-2019, considering both onshore and offshore events.

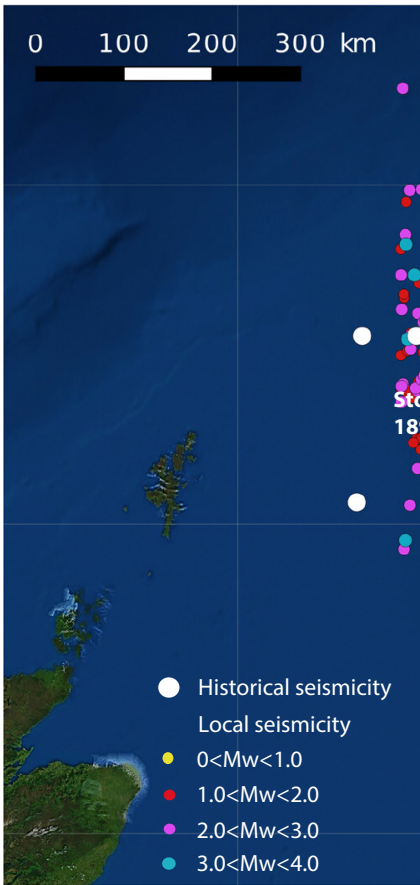

0
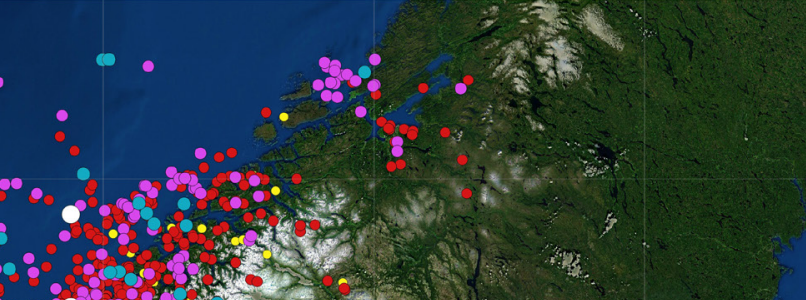

m
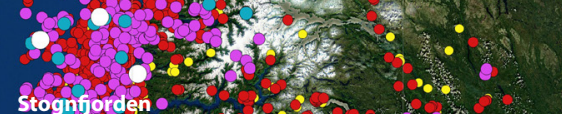

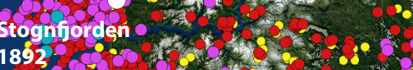

.

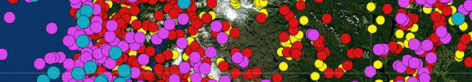

8
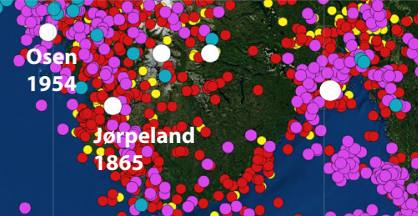

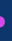

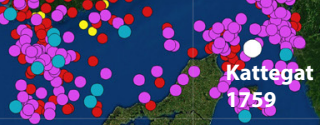

10

15

Longitude

Figure 4. Seismicity in southern Norway during the period 2000-2019. White dots correspond to the set of 13 historical seismic events recorded in southern Norway since 1657. 
According to the national network report (Norwegian National Seismic Network, 2018), around $52 \%$ of the registered activity in Norway corresponds to industrial and mining events. Those events, identified as probable or local explosions by the analysts, were not considered for the calculation. However, the identification of induced events is not a finished work, as they can exhibit different kinds of seismic traces which makes a clear distinction difficult.

Several high-magnitude events have occurred in Fennoscandia during the last centuries (Husebye et al., 1978; Ahjos \& Korhonen, 1984; Muir Wood \& Woo, 1987; Ahjos \& Uski, 1992; NORSAR \& NorwegianGeotechnical Institute,1998). Mostoftheavailableinformationcorrelatestheseismicactivity with tectonic features such as faults, lineaments and stress-field changes, as well as finding empirical relationships for seismic patterns and recurrence times (Båth, 1954; Kvale, 1960; Kárník, 1969, 1971; Husebye et al., 1978; Keiding et al., 2015; Gabrielsen et al., 2018). Generally, they are ranging between $4.5 \leq M_{w} \leq 6.0$ and are distributed along the western coast, the Telemark-Vänern Zone and the Bothnian Zone to the north (Fig. 4). As our study is focused on southern Norway, we selected 13 historical events within the area of interest which occurred between 1657 and 1986 to describe possible thermal effects derived from high-magnitude seismicity $\left(4.5 \leq M_{w} \leq 5.6\right)$ (Table 1 \& Fig. 4).

Table 1. Historical earthquakes in southern Norway classified by area, year and location (from http://nnsn.geo.uib.no/nnsn/\#/).

\begin{tabular}{lcccc}
\hline Earthquake & Year & Latitude $\left[^{\circ}\right]$ & Longitude $\left[{ }^{\circ}\right]$ & Magnitude, $\mathrm{Mw}$ \\
\hline Faenshølet & 1657 & 59.0 & 10.5 & 4.8 \\
Kattegat & 1759 & 57.7 & 11.1 & 5.6 \\
Hovden & 1774 & 59.5 & 7.0 & 4.6 \\
Åslandmoen & 1834 & 59.5 & 7.9 & 5.0 \\
Jørpeland & 1865 & 59.0 & 6.1 & 4.9 \\
Stongfjorden & 1892 & 61.4 & 5.1 & 5.2 \\
Osen & 1954 & 59.7 & 4.9 & 4.9 \\
Nordsjøen & 1977 & 61.7 & 2.3 & 4.6 \\
Nordsjøen & 1982 & 60.2 & 2.2 & 4.7 \\
Nordsjøen & 1986 & 61.7 & 3.3 & 4.5 \\
Norskehavet & 1986 & 62.7 & 4.4 & 4.8 \\
Norskehavet & 1988 & 63.7 & 2.4 & 4.7 \\
Nordsjøen & 1989 & 61.9 & 4.4 & 4.8 \\
\hline
\end{tabular}

To proceed with the calculation of the temperature increases and the heat related to the frictional energy, we will use the Kanamori's procedure using equations (4) and (1). The parameters will be determined for each event in the catalogue, doing separate calculations for local and historical seismicity, which will not be considered for the final amount of energy as no big or considerable events have occurred during the last 20 years. As was previously discussed, a reasonable value for the static stress drop is $\Delta \sigma_{s}=100$ bar. The frictional stress was calculated using equations (9) and (10) for initial tectonic stress ranging between a minimum of $\sigma_{0_{-} \min }=100$ bar and a maximum of $\sigma_{0_{-} \max }=150$ bar. According to this, the frictional stress range between $\sigma_{f_{-} \min }=5.25$ bar and $\sigma_{f_{-} \max }=49.5$ bar with an average of $\sigma_{f_{-} a v}=25$ bar. All the data were processed and filtered in Matlab ${ }^{\circledR}$, using codes elaborated by the authors. The 2D interpolations and visualizations were made in QGIS ${ }^{\circledR}$ and Oasis Montaj ${ }^{\circledR}$. 
From the seismogram analysis it is impossible to directly calculate the thickness of the heated zone, $w$. However, it can be observed in fault surface breaks and in laboratory experiments (Di Toro et al., 2006; Passelègue et al., 2016). In both cases, the co-seismic slip occurs in a very narrow zone and a good estimation can vary between 0.1 and $1 \mathrm{~cm}$ (Hubbert \& Rubey, 1959; Goldsby \& Tullis, 1998; Otsuki, 1998; Kanamori \& Heaton, 2000; Sibson, 2003; Caggianelli et al., 2005; Shipton et al., 2006). For this study, we will consider $w=1 \mathrm{~mm}$, in order to estimate the maximum amount of frictional energy that could be produced as an effect of seismic activity. Rigidity, specific heat and density, are considered as representative constants and their values were chosen as $\mu=0.3 \mathrm{Mbar}, \mathrm{C}=1 \mathrm{~J} / \mathrm{g}^{\circ} \mathrm{C}$ and $\rho=2.6 \mathrm{~g} / \mathrm{cm}^{3}$.

\section{Results and discussion}

\section{Temperature measurements \& seismological implications}

The temperature increases, $d T$, considering a thickness of $w=1 \mathrm{~mm}$, are shown in Fig. 5 . For the average frictional stress, $\sigma_{f_{-} a v}=25$ bar, the temperature values are in the range of $\sim 3.3^{\circ}$ to $\sim 61.6^{\circ} \mathrm{C}$ for magnitudes between $M_{w}=1.2$ and 3.7. The bars in Fig. 5, assigned to the maximum and minimum values of the initial tectonic stress show differences of one order of magnitude for larger earthquakes, with the highest temperature $122^{\circ} \mathrm{C}$ being for $\sigma_{f_{-} \max }=49.5$ bar.

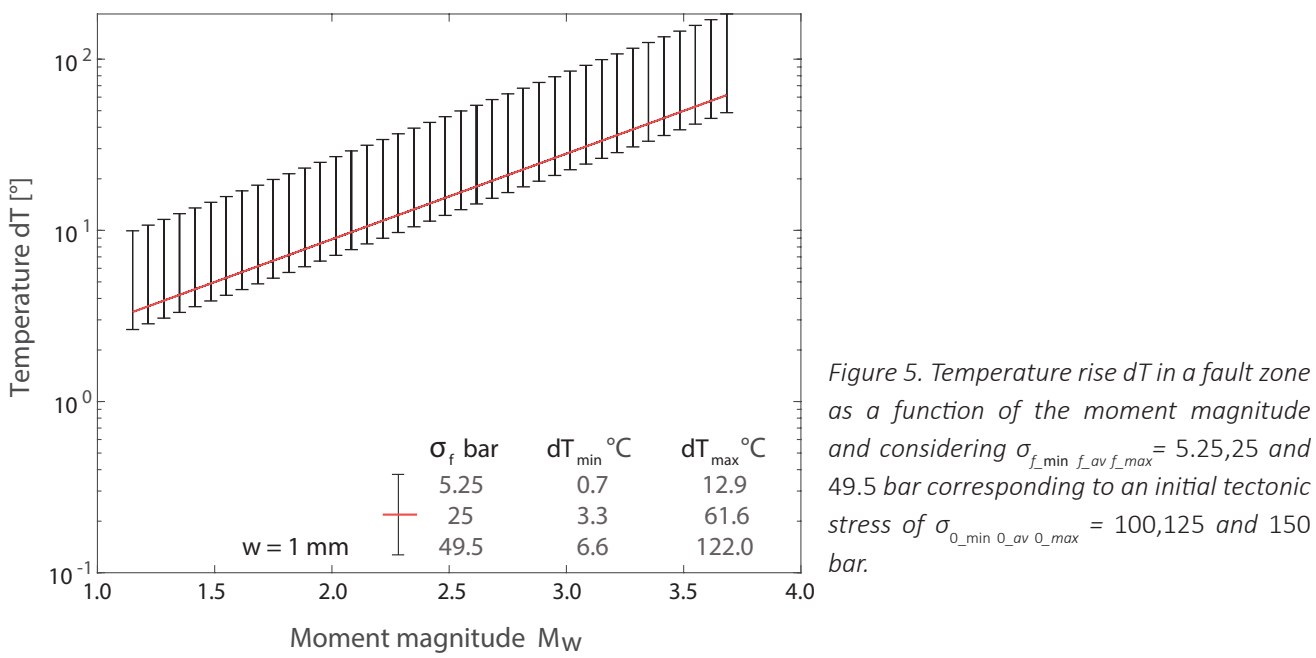

The temperatures were also derived for historical seismicity (Table 2). The obtained values are in the range of $157^{\circ}-559^{\circ} \mathrm{C}$ for magnitudes $M_{w}=4.5-5.6$.

The possible range of obtained temperatures, although limited, can lead to several thermomechanical effects. One of the main observed mechanisms for an enormous range of temperatures is the thermally induced cracking (Fredrich \& Wong, 1986; Browning et al., 2016; Daoud et al., 2020). In a controlled environment, even low thermal fluctuations between $15^{\circ} \mathrm{C}$ and $100^{\circ} \mathrm{C}$ ( $\mathrm{dT}_{\text {max }}$ for $\sigma_{\mathrm{f}_{\mathrm{a} a \mathrm{a}}}=25 \mathrm{bar}$ ), are capable of producing swarm activity, which enhances the fracture density (Warren \& Latham, 1970). As demonstrated by Fredrich \& Wong (1986), temperatures over $100^{\circ} \mathrm{C}$ $\left(d T_{\max }=122^{\circ} \mathrm{C}\right.$ at $\sigma_{f_{-} \max }=49.5 \mathrm{bar}$ ) are sufficient to produce thermal fractures in granite. For higher temperatures, the cracking response becomes more important, being present in most of the cases where temperature exceeds $300^{\circ} \mathrm{C}$ ( $d T$ for historical events) (Fredrich \& Wong, 1986). Additionally, the volumetric thermal expansion constitutes an important method for inducing microfracturing in rock 
Table 2. Seismic parameters and temperature increase for some historical earthquakes in southern Norway. Earthquakes with temperatures capable of generating frictional melting are marked in red. Earthquakes linked to a possible fluid pressurisation effect or/and the generation of cataclasites are marked in green. The frictional stress, stress drop and thickness used for the temperature calculation were $\sigma_{f a v}=25$ [bar], $\Delta \sigma=100[\mathrm{bar}]$ and $w=0.01 \mathrm{~cm}$, respectively.

\begin{tabular}{lccccc}
\hline Earthquake & $\mathrm{Mw}$ & $\begin{array}{c}\mathrm{M}_{0} \\
{\left[\times 10^{16} \mathrm{Nm}\right]}\end{array}$ & $\begin{array}{c}\mathrm{D} \\
{[\mathrm{m}]}\end{array}$ & $\begin{array}{c}\mathrm{S} \\
{\left[\times 10^{6} \mathrm{~m}^{2}\right]}\end{array}$ & {$\left[{ }^{\circ} \mathrm{C}\right]$} \\
\hline Faenshølet & 4.8 & 2.0 & 0.23 & 1.58 & 222.87 \\
Kattegat & 5.6 & 31.6 & 0.58 & 10.00 & 559.81 \\
Hovden & 4.6 & 1.0 & 0.18 & 1.00 & 177.03 \\
Åslandmoen & 5.0 & 4.0 & 0.29 & 2.51 & 280.57 \\
Jørpeland & 4.9 & 2.8 & 0.26 & 2.00 & 250.06 \\
Stongfjorden & 5.2 & 7.9 & 0.37 & 4.00 & 353.22 \\
Osen & 4.9 & 2.8 & 0.26 & 2.00 & 250.06 \\
Nordsjøen & 4.6 & 1.0 & 0.18 & 1.00 & 177.03 \\
Nordsjøen & 4.7 & 1.4 & 0.21 & 1.26 & 198.63 \\
Nordsjøen & 4.5 & 0.7 & 0.16 & 0.80 & 157.78 \\
Norskehavet & 4.8 & 2.0 & 0.23 & 1.60 & 222.87 \\
Norskehavet & 4.7 & 1.4 & 0.21 & 1.26 & 198.63 \\
Nordsjøen & 4.8 & 2.0 & 0.23 & 1.60 & 222.87 \\
\hline
\end{tabular}

samples at low temperature $\left(<100^{\circ} \mathrm{C}\right)$ (Wong \& Brace, 1979; Fredrich \& Wong, 1986; Robertson, 1988; Wulff \& Burkhardt, 1996). The thermally induced cracks can have a significant influence on the elastic moduli (Heard \& Page, 1982), porosity and local seismic velocities (Macbeth \& Shütt, 2007), seismic attenuation (Clark et al., 1981) and permeability, among others (Bauer \& Johnson, 1979). Moreover, Shat et al. (1984) suggested a substantial effect on the state of stress at shallow depths. Finally, the heat production in the fault core also contributes to the frictional drop of the slipping surface, for both low and high temperatures ranging from $10^{-2}$ to $10^{4}{ }^{\circ} \mathrm{C}$ (Passelègue et al., 2016). For our range of temperatures $\left(\sim 0.7^{\circ} \sim \sim 122^{\circ} \mathrm{C}\right)$ the dynamic friction coefficient may decrease from $\sim 0.7$ to $\sim 0.3$.

As observed in southern Norway, low-magnitude seismicity is continuously occurring in pre-existent zones of weakness with a low shear strength (Olesen et al., 2013b). We would like to evaluate if some of the cited thermo-mechanical effects contribute to the intraplate distribution, considering that seismic events are mostly located in highly fractured zones (Fig. 4) (Gabrielsen et al., 2002). However, whether or not there is some effect, such a conclusion is beyond the scope of this research. For now, we can only propose this mechanism as a new research area that must to be explored.

With mechanical effects, thermal processes become important for high-magnitude earthquakes, leading to higher temperatures (Kanamori \& Heaton, 2000). If no fluids are present in a fault zone, the temperature will rise to cause frictional melting, and cataclasites and pseudotachylites could be found as a result of large earthquakes $\left(M_{w}>5.0\right.$ ) (Lin, 1994a, b; Obata \& Karato, 1995; Otsuki, 1998; Kanamori $\&$ Heaton, 2000). Plausible temperature ranges for the formation of these types of rocks vary between $250^{\circ}-350^{\circ} \mathrm{C}$ and $600^{\circ}-1700^{\circ} \mathrm{C}$ for cataclasites and psseudotachylites, respectively (Niemeyer et al., 2004; Jiang et al., 2015). According to our results, at least one of the historical events, the Kattegat earthquake (Fig. 4), could have traces of pseudotachylites with an approximate formation temperature of $559.81^{\circ}$; 
however, to the best of our knowledge there is no evidence regarding this point so far. For the rest of the events, the temperatures are not high enough to melt the rock, leading to the possible presence of cataclasites and fault breccias. In this respect, a notable case is observed in the Hardangerfjord shear zone (Fig. 2) and the related lineament zone (Gabrielsen et al., 2002), which is reasonably linked with the 1865, 1892 and 1954 earthquakes (Table 1 \& Fig. 4). The fault zone exposes mylonites cut by cataclasites, incorporated as clasts in breccia and gouge zones (Gabrielsen et al., 2002), which, according to our estimates, could have a temperature formation between $250^{\circ}$ and $353^{\circ} \mathrm{C}$.

None of the previous analyses consider the high amount of groundwater circulation through cracks and fractures in southern Norway's upper crust. Maystrenko et al. (2015) established that tectonic effects attributed to the post-glacial rebound and the seismic activity in the southwestern area are enough to reactivate fractures which allow the fluid flow. Considering a constant recharge of meteoric water and its consequent circulation in the upper crust, the existing fluids could initiate fluid pressurisation (Sibson, 1973; Mase \& Smith, 1985, 1987), which enhances the total slip, slip velocity and shear-stress drop (French et al., 2016). Significant increases in the pore pressure can be registered with temperature variations at seismogenic depths, considering both the seismic effect and the temperature-pressure gradient (Kanamori \& Heaton, 2000). Even more, if permeability values are less than $10^{-18} \mathrm{~m}^{2}$, fluid pressurisation can be present even with low temperature increases. In this context, values between $100^{\circ}$ and $200^{\circ} \mathrm{C}$ are enough to drop the friction (Lachenbruch, 1980; Mase \& Smith, 1985, 1987). As a general crustal behaviour, permeability values vary between $10^{-12}$ and $10^{-18} \mathrm{~m}^{2}$ in the first ten kilometres of the crust (Ingebritsen \& Manning, 2010). Following this criterion, considering the shallowness of the Norwegian earthquakes, and the case $\sigma_{f_{-} \max }=49.5_{\text {bar }}$ with magnitudes above $M_{w}=3.5\left(\mathrm{dT}>100^{\circ} \mathrm{C}\right), 0.5 \%$ of the total local events could increase the pore pressure, thus enhancing the fracturing process (Fig. 3 ). With respect to the historical seismicity, all the earthquakes in Table 2 reach the required temperature for fluid pressurisation.

\section{Frictional energy \& heat flux}

The 3D map in Fig. 6A shows the thermal energy produced by each individual event. The highest values of the frictional energy are present to the west of the study area. These values are partially related to the higher amount of seismic activity located along the southwestern coast $\left(3^{\circ}-6^{\circ} \mathrm{E}\right)$, which corresponds to $53 \%$ of the total events (Figs. 6 \& 7). Additionally, the local magnitude distribution contributes to this value, being larger to the west where $M_{L}=1.58$ compared with a mean of $M_{L}=1.54$ to the east. Moreover, as can be observed in Fig. 4 , most of the earthquakes with magnitudes between $M_{w}=3.0$ and 4.0 are located along the western coast.

The amounts of frictional energy at every $10 \mathrm{~km}$ depth can be observed in Table 3. As would be expected, the net values decrease with depth, which relates to the shallowness of local seismicity (Pasquale et al., 2001; Olesen et al., 2013b; Norwegian National Seismic Network, 2018).

Compared to local seismicity, historical earthquakes as individual events exhibit frictional energies of one order of magnitude larger than the cumulative values for local activity (Fig. 6B).

The obtained results for the frictional energy were then calculated regionally using temporal steps of one year. The results are summarised in the Supplementary Material 1 and in Fig. 8. The amount of thermal energy remains relatively constant through the years which reflects the stability in the magnitude distribution and the number of events per year (Norwegian National Seismic Network, 2018) (Fig. 8). Additionally, these results propose some hypothesis about the possible dissipation and conversion mechanisms of the frictional energy by either reducing temperature or conversion to mechanical energy. According to Eq. 1, to maintain a stable value of the frictional energy requires 
A
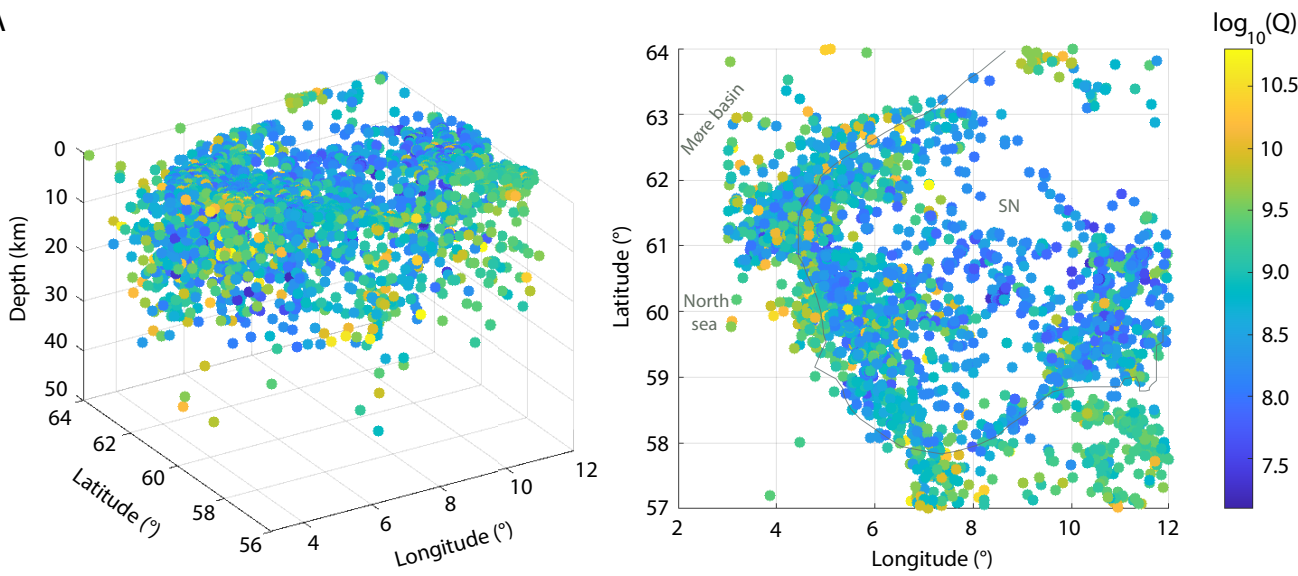

B

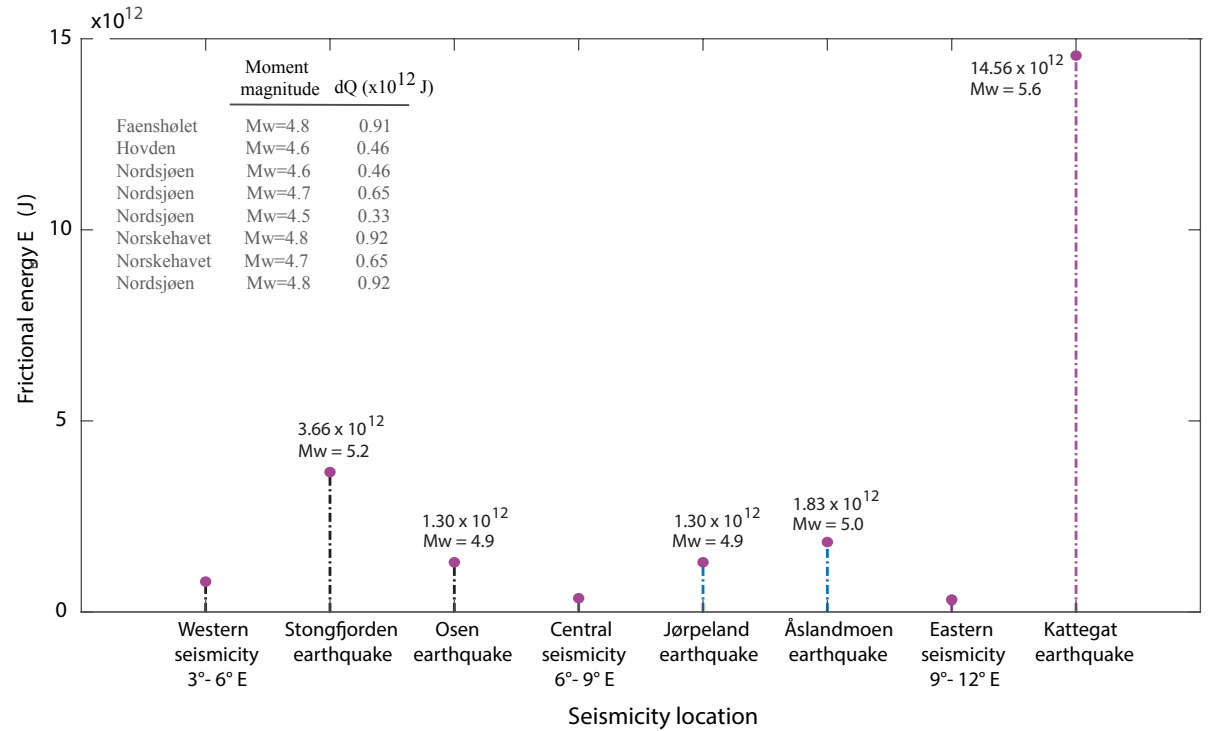

Figure 6. (A) 3D distribution of frictional energy $Q$ in southern Norway. All the registered local events were considered for this calculation. (left) Depth view. (right) Plan view. (B) Frictional energy comparison for local seismicity vs historical earthquakes. For comparative purposes, the area was divided longitudinally considering western, central and eastern events.

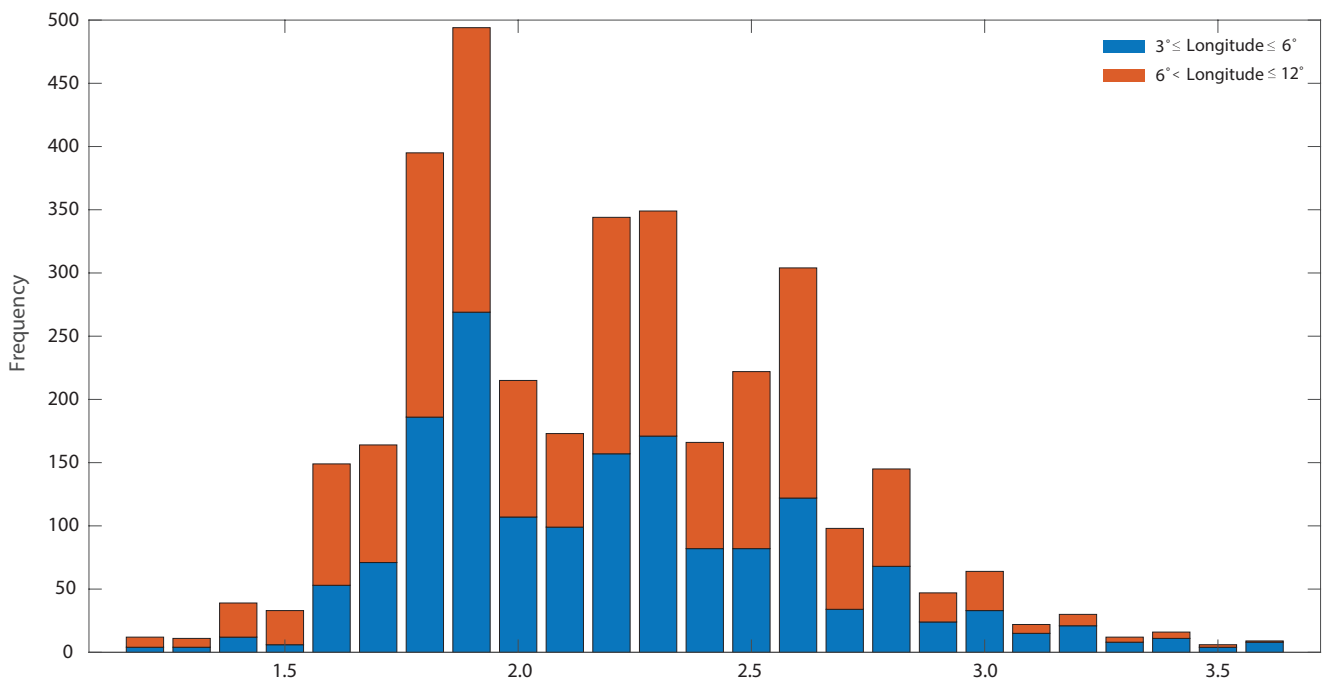

Moment magnitude $\mathrm{M}_{\mathrm{w}}$

Figure 7. Histogram of frequency vs moment magnitude divided for western and eastern seismic activity 
Table 3. Total amount of frictional energy every $10 \mathrm{~km}$ depth.

\begin{tabular}{cc}
\hline Depth $[\mathrm{km}]$ & Thermal energy $[\mathrm{J}] \times 10^{12}$ \\
\hline $\mathbf{0}-\mathbf{1 0}$ & 1.50 \\
$\mathbf{1 0 - 2 0}$ & 0.94 \\
$\mathbf{2 0 - 3 0}$ & 0.37 \\
$\mathbf{3 0 - 4 0}$ & 0.04 \\
\hline
\end{tabular}

no significant variations in the product between the fault area $(S)$ and the displacement offset (D). The latter implies that most frictional energy is not being used to generate or extend seismogenic structures. However, it is dissipated through a fast temperature reduction around the fault zone due to the thermal diffusivity, which is enhanced by the high amount of circulating fluids (atmospheric precipitation and/or groundwater movement) (Maystrenko et al., 2015). The high fracture density in southern Norway is also an advantage for a continuous advective cooling (Maystrenko et al., 2015), which acts in the short term during the faulting time $\tau_{0}$ - which is less than $10 \mathrm{~s}$ for most of the earthquakes (Kanamori \& Heaton, 2000) - and in the long term through the reduction of the thermal gradient (Maystrenko et al., 2015).

Motivated by our previous results, the frictional energy produced by all the events was calculated for the entire period, obtaining in this way the regional cumulative values. To improve the visualisation and locate spatially some possible anomalies in a $2 \mathrm{D}$ view, the area was gridded using a cell size of $0.8 \times 0.8$ degrees between $3^{\circ}-12^{\circ}$ E and $57^{\circ}-64^{\circ} \mathrm{N}$ (Fig. 9). A mean of 40 seismic events per cell was used for the interpolation and an independent total amount of $E_{H}$ was obtained for each cell.

The results indicate relatively high frictional energy values along the entire southwestern continental margin, being spatially related to the Bergen Zone (Fig. 2). In particular, a high peak of frictional energy is located in the northern North Sea $\left(Q>1.4 \times 10^{11} \mathrm{~J}\right)$, to the south of the Møre Basin, as is expected considering the seismicity distribution observed in the zone (Figs. 4, 6 \& 9). Intermediate values can be also found along the entire continental margin, where the frictional energy varies between $0.8 \times 10^{11} \mathrm{~J}$ $<Q<1.0 \times 10^{11} \mathrm{~J}$, finding within this range the highest value close to the Oslo Rift (Fig. 9). No significant amounts of frictional energy were recorded inland, where seismicity decreases in both magnitude and frequency.

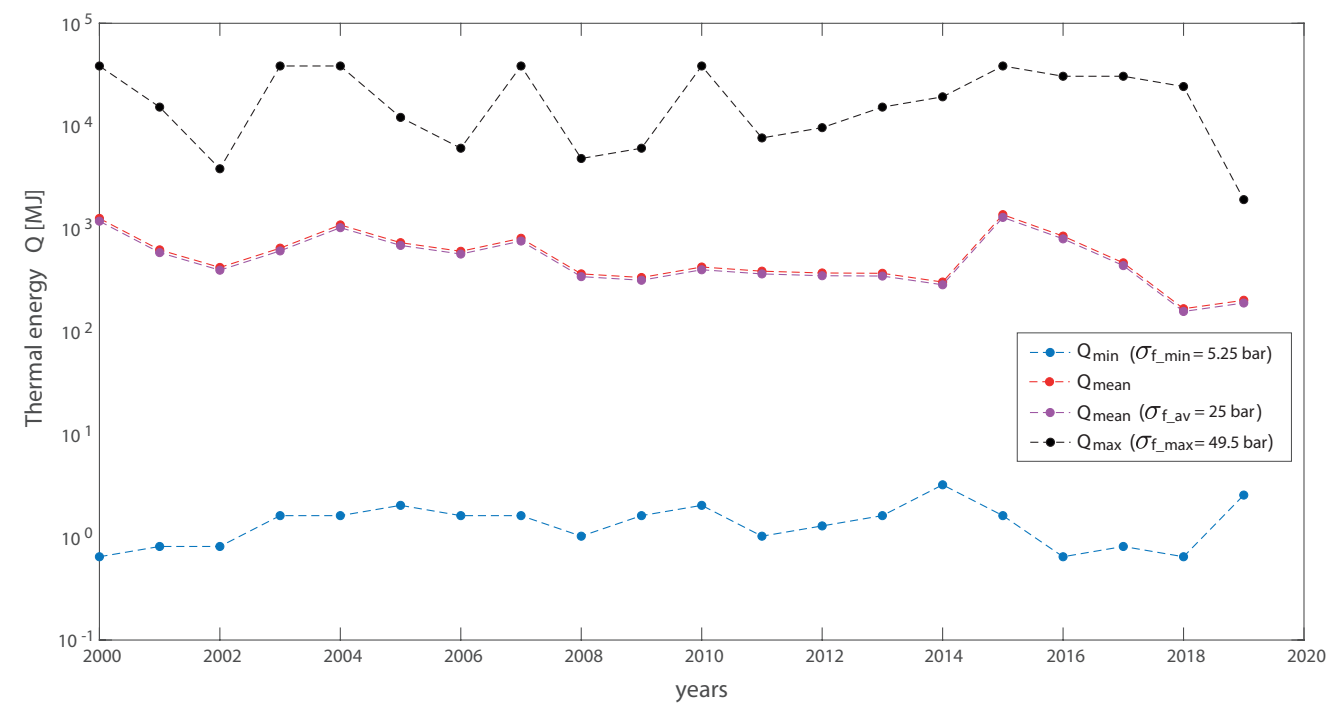

Figure 8. Frictional energy $Q$ per year considering maximum, minimum, average and mean values of $\sigma_{f}$. 

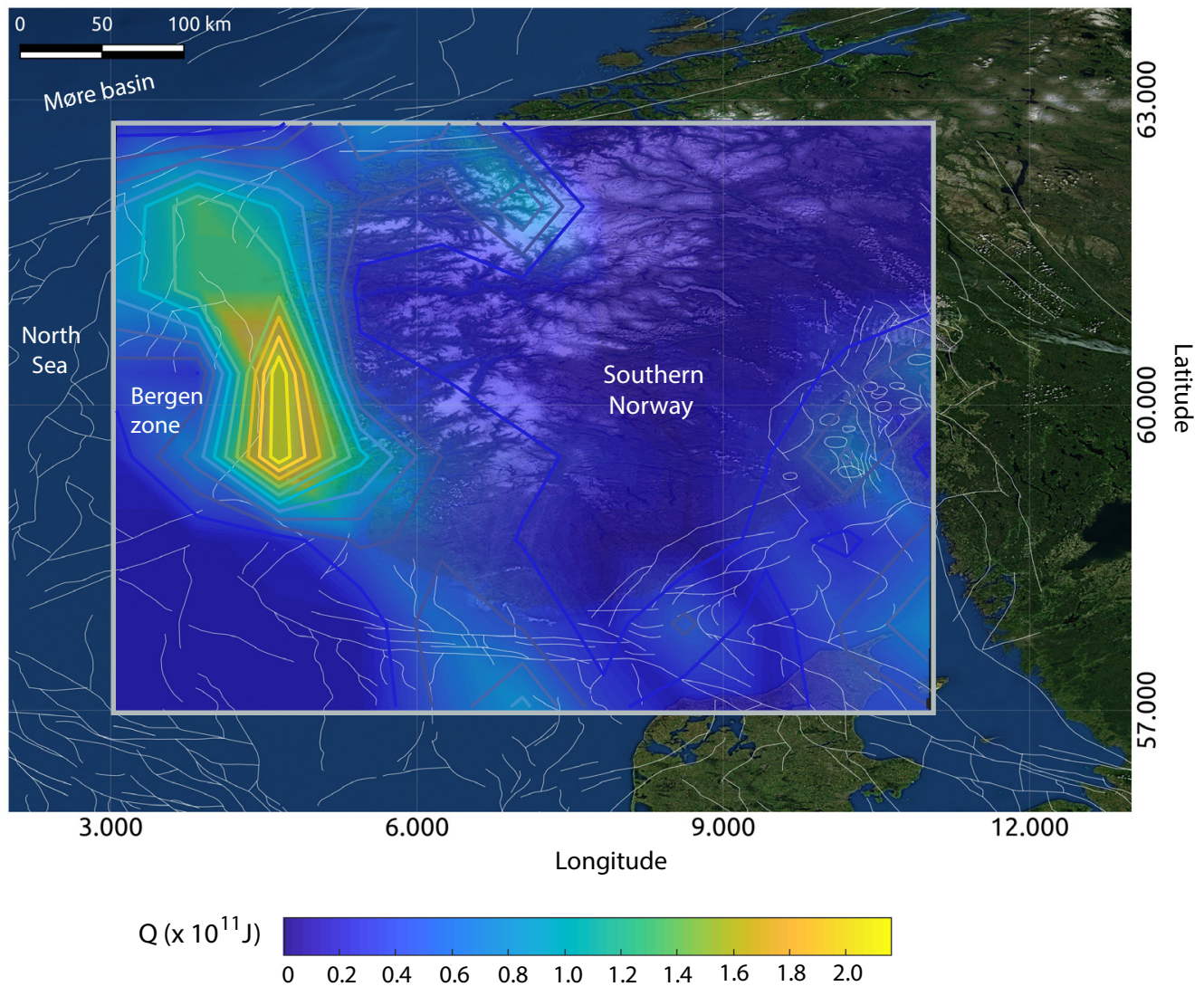

Figure 9. 2D cumulative thermal energy in southern Norway. Scale is showing the frictional energy values considering $\sigma_{f a v}=25$ bar. An offshore faults map can be found in the Norwegian Petroleum Directorate webpage (https://factpages.npd.no/).

The frictional energy map was also correlated with the Norwegian heat flux map (Olesen et al., 2013a, p. 260, fig. 14.2), shown in Fig. 10. Those results, which were based on a compilation of old and new regional datasets, show a strong correlation between the thickness of the crust and the heat-flow distribution, which reaches minimum values in the oldest areas. On the contrary, high amounts of heat flux ( $\sim 0-100 \mathrm{~mW} / \mathrm{m}^{2}$ ) were found along the southwestern margin and close to the Oslo area, which is spatially correlated with the presence of a few earthquakes with magnitudes $M_{w}=3.0-4.0$ and a high amount of low-magnitude seismicity, e.g., of frictional energy (Figs. 4 \& 10). These findings suggest a possible connection between the seismic activity and the crustal heat flux. Regarding this, it would be interesting to analyse if the heating process during the co-seismic period contributes in some way to the crustal heat-flux measurements. Previous studies indicate that areas with a relatively high heat flow are connected to a swarm-type temporal distribution of seismicity (Pasquale et al., 2001; Enescu et al., 2009). For the Norwegian seismic activity, which seems to be Poisson distributed (Olesen et al., 2013b), these findings open a new path to explore the probable formation of seismic sequences related to a swarm-like behaviour at least in the area that has been analysed in this study. As the data availability probably strongly influences the heat-flux anomaly map, these associations could be improved with the publication of new and more complete datasets, helping us to better constrain, for example, the Møre Basin area, which was not fully analysed on this occasion. 


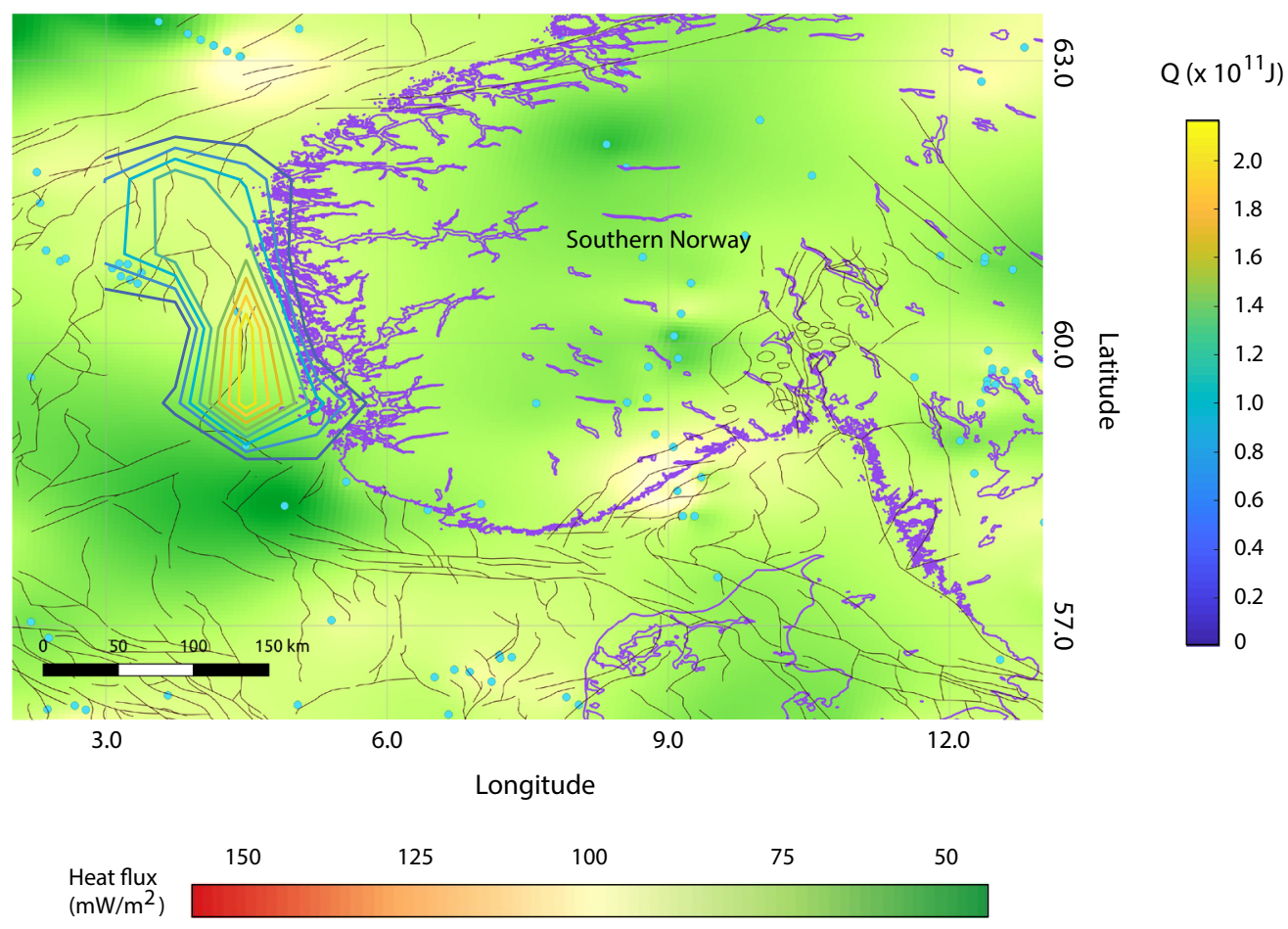

Figure 10. Heat-flux map of Norway modified from Olesen et al., (2013a). The map is including a contour plot showing the areas with high frictional energy, which can also be observed in Fig. 9. The scale indicates the thermal energy values for the contour lines. An oOffshore faults map can be found in the Norwegian Petroleum Directorate webpage (https://factpages.npd.no/).

\section{Outlook and conclusions}

In southern Norway, sudden temperature increases were calculated from the local seismic events during the period 2000-2019. For this purpose, we used a simple stress drop model and the initial tectonic stresses previously calculated for southern Norway to estimate frictional stresses under a constant static stress drop. The obtained values are ranging from $3.3^{\circ} \mathrm{C}$ to $61.6^{\circ} \mathrm{C}$ for an average frictional stress of $\sigma_{f_{-} a v}=25$ bar. However, the maximum obtained temperature was $122^{\circ} \mathrm{C}$ for the maximum frictional stress $\sigma_{f_{-} \max }=49.5$ bar. Additionally, temperatures for historical events between 1657 and 1989 were calculated for the average stress value. The obtained values are in the range of $157^{\circ}-559^{\circ} \mathrm{C}$ for magnitudes $M_{w}=4.5-5.6$. Depending on the temperature range, these outcomes can lead to a great variety of thermal effects such as a change in frictional coefficients, thermally induced microfracturing (all calculated temperatures), fluid pressurisation $\left(100^{\circ}-200^{\circ} \mathrm{C}\right)$ and rock melting $\left(>500^{\circ} \mathrm{C}\right)$.

An estimation of the total frictional energy generated by the seismic events indicates production of around $1.50 \times 10^{12} \mathrm{~J}$ for the ten first kilometres of the crust, which decreases quite reasonably agreeing with the seismicity distribution at depth (Pasquale et al., 2001). The study area's western zone presents the largest amount of frictional energy reaching a cumulative value of $2.0 \times 10^{11} \mathrm{~J}$ in the entire period. These cumulative results for frictional energy were projected on a 2D heat-flux map compilation from the years 1974 to 2010 (see references above and Olesen et al., 2013a). We could thus find a spatial matching between seismicity location and high heat-flux areas from this correlation, which may give some insights about the swarm-type distribution of the intraplate activity. Additionally, as a hypothesis that must be studied in detail, we would suggest that the seismic thermal processes may have some influence on the heat flux in the region. 
The dissipation effects are patent observing how the frictional energy remains approximately constant throughout the entire period considering steps of one year (Fig. 8). This dissipation of the co-seismic thermal energy is probably mainly related to a fast temperature reduction, where the high amount of fluid circulation and the thermal dissipation coefficients of the crustal rocks play a key role. Some extrapolations to the past, for example, towards the period of Quaternary glaciation, may help to resolve this issue.

Acknowledgments. This research was partially funded by the Universidad Técnica Federico Santa María, with the project entitled 'Sismicidad inducida y energía térmica: aplicación al peligro sísmico y las energias renovables (In spanish)', ID number PI_M_1904. At the same time, the seismological results are part of the Postdoctoral fellowship 'Seismic Imaging using Norwegian Earthquakes -SINE-' project number 74200005, which belongs to the Becas Chile program. The authors want to thank to the Geological Survey of Norway (NGU) as the hosting institution. C.P and M.B also thank Yuriy Maystrenko and Sara Rezaei for helpful and constructive discussions. All the authors want to express their gratitude to the reviewers for their useful comments and suggestions.

Author contribution statement. C. Pavez and R. Estay conceived and designed the analysis and performed the main calculations. M. Brönner contributed with the analysis of the obtained results. All the previous authors, including A. Ortiz, contributed with the discussions and main conclusions. F. de Barbieri, L. Guzmán and J.P. Ibanez participated in minor revisions. All the authors contributed in revising the final version of the article.

\section{References}

Abercrombie, R.E. \& Leary, P. 1993: Source parameters of small earthquakes recorded at $2.5 \mathrm{~km}$ depth, Cajon Pass, southern California: Implications for earthquake scaling. Geophysical Research Letters 20, 1511-1514. https://doi.org/10.1029/93GL00367.

Abercrombie, R.E. \& Rice, J.R. 2005: Can observations of earthquake scaling constrain slip weakening? Geophysical Journal International 162, 406-424. https://doi.org/10.1111/j.1365-246X.2005.02579.x.

Ahjos, T. \& Korhonen, H. 1984: On a catalogue of historical earthquakes in Fennoscandian areas. Institute of seismology University of Helsinki report S-10, 24 pp.

Ahjos, T. \& Uski, M. 1992: Earthquakes in northern Europe in 1375-1989. Tectonophysics 207, 1-23. https://doi.org/10.1016/0040-1951(92)90469-M.

Alsaker, A., Kvamme, L.B., Hansen, R.A., Dahle, A. \& Bungum, H. 1991: The ML scale in Norway. Bulletin of the Seismological Society of America 81, 379-398. https://doi.org/10.21236/ADA226859.

Aubry, J., Passelègue, F.X., Deldicque, D., Girault, F., Marty, S., Lahfid, A., Bhat, H.S., Escartin, J. \& Schubnel, A. 2018: Frictional heating processes and energy budget during laboratory earthquakes. Geophysical Research Letters 12, 274-282. https://doi.org/10.1029/2018GL079263.

Badley, M.E., Egeberg, T. \& Nipen, O. 1984: Development of rift basins illustrated by the structural evolution of the Oseberg structure, Block 30/6, offshore Norway. Journal of the Geological Society 141, 639-649. https://doi.org/10.1144/gsjgs.141.4.0639. 
Bannister, S.C., Ruud, B.O. \& Husebye, E.S. 1991: Tomographic estimates of sub-Moho seismic velocities in Fennoscandia and structural implications. Tectonophysics 189, 37-53.

https://doi.org/10.1016/0040-1951(91)90486-C.

Bauer, S.J. \& Johnson, B. 1979: Effects of slow uniform heating on the physical properties of the Westerly and Charcoal granites. Proceedings, $20^{\text {th }}$ U.S. Symposium on Rock Mechanics, 4-6 June, Austin, Texas, United States of America, p. 7.

Beeler, N.M., Tullis, T.E. \& Goldsby, D.L. 2008: Constitutive relationships and physical basis of fault strength due to flash heating. Journal of Geophysical Research 113, 401-413.

https://doi.org/10.1029/2007JB004988.

Bethmann, F., Deichmann, N. \& Mai, P.N. 2011: Scaling relations of local magnitude versus moment magnitude for sequences of similar earthquakes in Switzerland. Bulletin of the Seismological Society of America 101, 515-534. https://doi.org/10.1785/0120100179.

Browning, J., Meredith, P. \& Gudmundsson, A. 2016: Cooling-dominated cracking in thermally stressed volcanic rocks. Geophysical Research Letter 43, 8417-8425. https://doi.org/10.1002/2016GL070532.

Bungum, H., Lindholm, C.D., Dahle, A., Woo, G., Nadim, F., Holme, J.K., Gudmestad, O.T., Hagberg, T. \& Karthigeyan, K. 2000: New seismic zoning maps for Norway, the North Sea, and the United Kingdom. Seismological Research Letters 71, 687-697. https://doi.org/10.1785/gssrl.71.6.687.

Byerlee, J.D. 1976: Friction of rocks. Pure and Applied Geophysics 116, 615-626.

https://doi.org/10.1007/BF00876528.

Bøe, R., Fossen, H. \& Smelror, M. 2010: Mesozoic sediments and structures onshore Norway and in the coastal zone. Norges geologiske undersøkelse Bulletin 450, 15-32.

Båth, M. 1954: Seismicity of Fennoscandia and related problems. Gerlands Beitrage zur Geophysik 63, 173-208.

Caggianelli. A., de Lorenzo, D. \& Prosser. G. 2005: Modelling the heat pulses generated on a fault plane during co-seismic slip: Inferences from the pseudotachylites of the Copanello cliffs (Calabria, Italy). Tectonophysics 405, 99-119. https://doi.org/10.1016/j.tecto.2005.05.017.

Clark, V.A., Spencer, T.W. \& Tittmann, B.R. 1981: The effect of thermal cycling on the seismic quality factor Q of some sedimentary rocks. Geophysical Research 86, 7087-7094. https://doi.org/10.1029/JB086iB08p07087.

Daoud, A., Browning, J., Meredith, P.G. \& Mitchell, T.M. 2020: Microstructural controls on thermal crack damage and the presence of a temperature-memory effect during cyclic thermal stressing of rocks. Geophysical Research Letters 47. https://doi.org/10.1029/2020GL088693.

Deichmann, N. 2006: Local magnitude, a moment revisited. Bulletin of the Seismological Society of America 96, 1267-1277. https://doi.org/10.1785/0120050115.

Di Toro, G., Hirose, T., Nielsen, S., Pennacchioni, G. \& Shimamoto, T. 2006: Natural and experimental evidence of melt lubrication of faults during earthquakes. Science 311, 647-649.

https://doi.org/10.1126/science.1121012. 
Di Toro, G., Han, R., Hirose, T., De Paola, N., Nielsen, S., Mizoguchi, K., Ferri, F., Cocco, M. \& Shimamoto, T. 2011: Fault lubrication during earthquakes. Nature 471, 494-498. https://doi.org/10.1038/nature09838.

Enescu, B., Hainzl, S. \& Ben-Zion, Y. 2009: Correlations of Seismicity Patterns in Southern California with Surface Heat Flow Data. Bulletin of the Seismological Society of America 99, 3114-3123. https://doi.org/10.1785/0120080038.

Eriksson, K.G. \& Malmqvist, D. 1979: A review of the past and present investigations of heat flow in Sweden. In Cemak, V \& Rybach, L (eds.): Terrestrial Heat Flow in Europe, Springer, Berlin, pp. $267-277$. https://doi.org/10.1007/978-3-642-95357-6_28.

Eshelby, J.D. 1957: The determination of the elastic field of an ellipsoidal inclusion and related problems. Proceedings of the Royal Society 241, 376-396. https://doi.org/10.1098/rspa.1957.0133.

Fejerskov, M. \& Lindholm, C. 2000: Crustal stress in and around Norway: an evaluation of stress generating mechanisms. In Nøddvet, A. (ed.): Dynamics of the Norwegian Margin, Geological Society Special Publication 167, pp. 451-467. https://doi.org/10.1144/GSL.SP.2000.167.01.19.

Fjeldskaar, W., Lindholm, C., Dehls, J.F. \& Fjeldskaar, I. 2000: Post-glacial uplift, neotectonics and seismicity in Fennoscandia. Quaternary Science Reviews 19, 1413-1422.

https://doi.org/10.1016/S0277-3791(00)00070-6.

Fredrich, J.T., \& Wong, T. 1986: Micromechanics of thermally induced cracking in three crustal rocks. Journal of Geophysical Research 91, 12743-12764. https://doi.org/10.1029/JB091iB12p12743.

French, M., Zhu, W. \& Banker J. 2016: Fault slip controlled by stress path and fluid pressurization rate. Geophysical Research Letters 43, 4330-4339. https://doi.org/10.1002/2016GL068893.

Færseth, R.B., Sjøblom, T.S., Steel, R.J., Liljedahl, T., Sauar, B.E. \& Tjelland, T. 1995: Tectonic controls on Bathonian-Volgian syn-rift successions on the Visund fault block, northern North Sea. Norwegian Petroleum Society Special Publication 5, 325-346. https://doi.org/10.1016/S0928-8937(06)80074-3.

Gabrielsen, R.H. 1986: Structural elements in graben systems and their influence on hydrocarbon trap types. In Spencer, A.M. (ed.): Habitat of Hydrocarbons on the Norwegian Continental Shelf, Norwegian Petroleum Society, pp. 55-60.

Gabrielsen, R.H. 1989: Reactivation of faults on the Norwegian continental shelf and its implications for earthquake occurrence. In Geregeresen, S. \& Basham, P.W. (eds.): Earthquakes at the North Atlantic Passive Margins: Neotectonics and Post-glacial rebound, Kluwer Academic Publishers, pp. 67-90. https://doi.org/10.1007/978-94-009-2311-9_6.

Gabrielsen, R.H., Braathen, A., Dehls, J. \& Roberts, D. 2002: Tectonic lineaments of Norway. Norwegian Journal of Geology 82, 153-174.

Gabrielsen, R.H., Nystuen, J.P. \& Olesen, O. 2018: Fault distribution in the Precambiram basement of South Norway. Journal of Structural Geology 108, 269-289. https://doi.org/10.1016/j.jsg.2017.06.006.

Goldsby, D.L. \& Tullis, T.E. 1998: Experimental observations of frictional weakening during large and rapid slip (abstract), EOS Transactions American Geophysical Union 79, F610. 
Goldsby, D.L. \& Tullis, T.E. 2011: Flash heating leads to low frictional strength of crustal rocks at earthquake slip rates. Science 334, 216-218. https://doi.org/10.1126/science.1207902.

Hanks, T.C. \& Kanamori, H. 1979: A moment magnitude scale. Journal of Geophysical Research 84, 2348-2350. https://doi.org/10.1029/JB084iB05p02348.

Hayward, K.S., Cox, S., Fitzgerald, J., Slagmolen, B., Shaddock, R., Forsyth, P., Salmon, M. \& Hawkins R. 2016: Mechanical amorphization, flash heating and frictional melting: Dramatic changes to fault surfaces during the first millisecond of earthquake slip. Geology 44, 1043-1046.

https://doi.org/10.1130/G38242.1.

Heard, H.C. \& Page, L. 1982: Elastic modulli, thermal expansion and inferred permeability of two granites to $350 \mathrm{C}$ and $55 \mathrm{MPa}$. Journal of Geophysical Research 87, 9340-9348. https://doi.org/10.1029/JB087iB11p09340.

Heier, K.S. \& Grønlie, G. 1977: Heat flow-heat generation studies in Norway. In Saxena, S.K. \& Bhattacharji, S. (eds.): Energetics of geological processes, Springer-Verlag, pp. 217-235. https://doi.org/10.1007/978-3-642-86574-9_11.

Hejrani, B., Balling, N., Jacobsen, B.H. \& England, R. 2017: Upper-mantle velocities below the Scandinavian Mountains from P- and S- wave traveltime tomography. Geophysical Journal International 208, 177-192. https://doi.org/10.1093/gji/ggw370.

Hubbert, M.K. \& Rubey, W.W. 1959: Role of fluid pressure in mechanics of overthrust faulting. Bulletin of Geological Society of America 70, 115-166. https://doi.org/10.1130/0016-7606(1959)70[115:ROFPIM]2.0.CO;2.

Husebye, E.S., Bungum, H., Fyen, J. \& Gjøystdal, H. 1978: Earthquake activity in Fennoscandia between 1497 and 1975 and intraplate tectonics. Norwegian Journal of Geology 1, Vol. 58, 51-68.

Ingebritsen, S.E. \& Manning, C.E. 2010: Permeability of the continental crust: dynamic variations inferred from seismicity and metamorphism. Geofluids 10, 193-205.

https://doi.org/10.1002/9781444394900.ch13.

Jiang, H., Lee, C.A., Morgan, J.K. \& Ross, C.H. 2015: Geochemistry and thermodynamics of an earthquake: A case study of pseudotachylites within mylonitic granitoid. Earth and planetary science letters 430, 235-248. https://doi.org/10.1016/j.epsl.2015.08.027.

Kanamori, H. 2001: Energy Budget of Earthquakes and Seismic Efficiency. In Teisseyre, R. \& Majewski, E. (eds.): Earthquake Thermodynamics and Phase Transformations in the Earth's Interior, International geophysics series 76, pp. 293-305. https://doi.org/10.1016/S0074-6142(01)80087-5.

Kanamori, H. \& Anderson, D. 1975: Theoretical basis of some empirical relations in seismology. Bulletin of the Seismological Society of America 65, 1073-1095.

Kanamori, H. \& Heaton, T. 2000: Microscopic and macroscopic physics of earthquakes. In Rundle, J.B., Turcotte, D.L. \& Klein, W. (eds.): Geocomplexity and the Physics of Earthquakes, Geophysical Monograph Series 120, pp. 147-163. https://doi.org/10.1029/GM120p0147. 
Kanamori, H. \& Rivera, L. 2006: Energy Partitioning During an Earthquake. In Abercrombie, R., McGarr, A., Di Toro, G. \& Kanamori, H. (eds.): Earthquakes: Radiated Energy and the Physics of Faulting, Geophysical Monograph Series 170, 99. 3-13. https://doi.org/10.1029/170GM03.

Kanamori, H., Anderson, D.L. \& Heaton, T.H. 1998: Frictional melting during the rupture of the 1994 Bolivian earthquake. Science 279, 839-842. https://doi.org/10.1126/science.279.5352.839.

Kárník, V. 1969: Seismicity of the European area. Vol I. Springer Netherlands, 364 pp.

Kárník, V. 1971: Seismicity of the European area. Vol II. Springer Netherlands, 218 pp. https://doi.org/10.1007/978-94-010-3078-6.

Karpuz, M.R., Gabrielsen, R.H., Engell-Sørensen, L. \& Anundsen, K. 1991: Seismotectonic significance of the January 29, 1989 Etne earthquake, southwest Norway. Terra Nova 3, 540-549.

https://doi.org/10.1111/j.1365-3121.1991.tb00189.x.

Keiding, M., Kreemer, C., Lindholm, C.D., Gradmann, S., Olesen, O. \& Kierulf, H.P. 2015: A comparison of strain rates and seismicity for Fennoscandia: depth dependency of deformation from glacial isostatic adjustment. Geophysical Journal International 202, 1021-1028. https://doi.org/10.1093/gji/ggv207.

Keilis-Borok, V.I. 1959: On the estimation of the displacement in an earthquake source and of source dimensions. Annals of Geophysics 12, 205-214.

Knopoff, L. 1958: Energy release in earthquakes. Geophysical Journal International 1, 44-52. https://doi.org/10.1111/j.1365-246X.1958.tb00033.x.

Kolstrup, M.L., Hung, S.H. \& Maupin, V. 2015: Multiscale finite frequency P and S tomography of the upper mantle in the south-western Fennoscandian Shield. Geophysical Journal International 202, 190-218. https://doi.org/10.1093/gji/ggv130.

Kvale, A. 1960: Norwegian earthquakes in relation to tectonics. Årbok University of Bergen, Mat-Naturv, Bergen Series 10, 17 pp.

Lachenbruch, A.H. 1980: Frictional heating, fluids pressure, and the resistance to fault motion. Journal of Geophysical Research 85, 6185-6222. https://doi.org/10.1029/JB085iB11p06097.

Lin, A. 1994a: Glassy pseudotachylyte veins from the Fuyun fault zone, northwest China. Journal of Structural Geology 16, 71-83. https://doi.org/10.1016/0191-8141(94)90019-1.

Lin, A. 1994b: Microlite morphology and chemistry in pseudotachylyte from the Fuyun fault zone, China. Journal of Geology 102, 317-329. https://doi.org/10.1086/629674.

Macbeth, C. \& Schütt, H. 2007: The stress dependent elastic properties of thermally induced microfractures in aeolian Rotliegend sandstone. Geophysical prospecting 55, 323-332.

https://doi.org/10.1111/j.1365-2478.2007.00601.x.

Madariaga, R. 1977: Implications of stress drop models of earthquakes from the inversion of stress drop from seismic observations. Pure and Applied Geophysics 115, 301-316.

https://doi.org/10.1007/978-3-0348-5745-1_19. 
Mase, C.W. \& Smith L. 1985: Pore-fluid pressures and frictional heating on a fault surface. Pure and Applied Geophysics 122, 583-607. https://doi.org/10.1007/BF00874618.

Mase, C.W. \& Smith, L. 1987: Effects of frictional heating on the thermal, hydrologic and mechanical response of a fault. Journal of Geophysical Research 92, 6249-6272.

https://doi.org/10.1029/JB092іB07p06249.

Maystrenko, Y., Olesen, O. \& Elvebakk, H.K. 2015: Indication of deep groundwater flow through the crystalline rocks of southern Norway. Geology 43, 327-330. https://doi.org/10.1130/G36318.1.

Maystrenko, Y.P., Brönner, M., Olesen, O., Saloranta, T.M. \& Slagstad, T. 2018: Is intraplate seismicity in Norway related to elevated atmospheric precipitation rates and low-velocity upper mantle? Abstract, American Geophysical Union Fall Meeting, 10-14 December, Washington, USA, S11D-0384.

Maystrenko, Y.P., Brönner, M., Olesen, O., Saloranta, T.M. \& Slagstad, T. 2020: Atmospheric precipitation and anomalous upper mantle in relation to intraplate seismicity in Norway. Tectonics 39. https://doi.org/10.1029/2020TC006070.

Melosh, H.J. 1996: Dynamical weakening of faults by acoustic fluidization. Nature 379, 601-606. https://doi.org/10.1038/379601a0.

Muir Wood, R. \& Woo, G. 1987: The historical seismicity of the Norwegian continental shelf (ELOCS), NGI Report No. 2-1, 116 pp.

Munafo, I., Malagnini, L. \& Chiaraluce, L. 2016: On the relationship between $M_{w}$ and $M_{L}$ for small earthquakes. Bulletin of the Seismological Society of America 106, 2402-2408.

https://doi.org/10.1785/0120160130.

Nielsen, S., Spagnuolo, E., Violay, M., Smith, S., Di Toro, G. \& Bistacchi, A. 2016. Fracture energy, friction and dissipation in earthquakes. Journal of Seismology 20, 1187-1205.

https://doi.org/10.1007/s10950-016-9560-1.

Niemeyer, H., Berrios, H. \& Ruiz Cruz, M.D. 2004: Temperatures of formation in Triassic cataclasites of Cordillera Domeyko, Antofagasta, Chile. Revista Geológica de Chile 31, 3-18. https://doi.org/10.4067/S0716-02082004000100001.

NORSAR \& Norwegian Geotechnical Institute. 1998: Development of a seismic zonation for Norway, NGI Final Report 963012-1, 187 pp.

Norwegian National Seismic Network. 2018: Annual report for the Norwegian National Seismic Network 2017. University of Bergen Report, 55 pp.

Norwegian Petroleum Directorate: Factpages. https://factpages.npd.no/ (accessed May, 2019)

Obata, M. \& Karato, S. 1995: Ultramafic pseudotachylite from the Balmuccia peridotite, Ivrea-Bervano zone, northern Italy. Tectonophysics 242, 313-328. https://doi.org/10.1016/0040-1951(94)00228-2.

Olesen, O., Balling, N., Barrère, C., Breiner, N., Davidsen, B., Ebbing, J., Elvebakk, H., Gernigon, L., Koziel, J., Lutro, O., Midttømme, K., Nordgulen, Ø., Olsen, L., Osmundsen, P.T., Pascal, C., Ramstad, R.K., Rønning, J.S., Skilbrei, J.R., Slagstad, T. \& Wissing, B. 2007: KONTIKI Final Report, CONTInental Crust and Heat Generation In 3D. NGU Report 2007.042, 438 pp. 
Olesen, O., Brönner, M., Ebbing, J., Elvebakk, H., Gellein, J., Koziel, J., Lauritsen, T., Lutro, O., Maystrenko, Y., Müller, C., Nasuti, A., Osmundsen, P.T., Slagstad, T. \& Storrø, G. 2013a: Coop Phase I-Crustal Onshore-Offshore Project. NGU Report 2013.002, 359 pp.

Olesen, O., Bungum, H., Dehld, J., Londholm, C., Pascal, C. \& Roberts, D. 2013b: Neotectonics, seismicity and contemporary stress field in Norway, mechanisms and implications. In Olsen, L., Fredin, O. \& Olesen, O. (eds.): Quaternary Geology of Norway, Geological Survey of Norway Special Publication 13 , pp. 145-174.

Otsuki, K. 1998: Physical process of seismic frictional sliding observed in samples from fault zones (in Japanese). Chikyu Monthly 19, 213-224.

Ottemöller, L. \& Sargeant, S. 2013: A Local Magnitude Scale ML for the United Kingdom. Bulletin of the Seismological Society of America 103, 2884-2893. https://doi.org/10.1785/0120130085.

Ottemöller, L., Strømme, M.L. \& Storheim, B.M. 2018: Seismic monitoring and data processing at the Norwegian National Seismic Network. Summary of the Bulletin of the International Seismological Centre 2015 52, 27-40. https://doi.org/10.31905/1M97CSYL.

Pascal, C. 2009: Erogen 08: Heat flow determinations in the Norwegian-Danish Basin. NGU Report 2009.046, $24 \mathrm{pp}$.

Pascal, C. \& Midttømme, K. 2006: Impact of recent glacial erosion on subsurface temperatures: the Mid-Norwegian Margin. NGU Report 2006.088, 25 pp.

Pascal, C., Balling, N., Barrère, C., Davidsen, B., Ebbing, J., Elvebakk, H., Mesli, M., Roberts, D., Slagstad, T. \& Willemoes-Wissing, B. 2010: HeatBar Final Report 2010, Basement Heat Generation and Heat Flow in the western Barents Sea - Importance for hydrocarbon systems. NGU Report 2010.030, 91 pp.

Pasquale, V., Verdoya, M. \& Chiozzi, P. 2001: Heat flux and seismicity in the Fennoscandian Shield. Physics of the Earth and Planetary Interiors 126, 147-162. https://doi.org/10.1016/S0031-9201(01)00252-7.

Passelègue, F., Schubnel, A., Nielsen, S., Bhat, H., Deldicque, D. \& Madariaga, R. 2016: Dynamic rupture processes inferred from laboratory microearthquakes. Journal of Geophysical Research: Solid Earth 121, 4343-4365. https://doi.org/10.1002/2015JB012694.

Pluymakers, A.M.H., Samuelson, J.E., Niemeijer, A.R. \& Spiers, C.J. 2014: Effects of temperature and CO2 on the frictional behavior of simulated anhydrite fault rock. Journal of Geophysical Research: Solid Earth 119, 8728- 8747. https://doi.org/10.1002/2014JB011575.

Rice, J.R. 2006: Heating and weakening of faults during earthquake slip. Journal of Geophysical Research 111, 311-340. https://doi.org/10.1029/2005JB004006.

Ritter, U., Zielinski, G.W., Weiss, H.M., Zielinski, R.L.B. \& Sættem, J. 2004: Heat flow in the Vøring Basin, Mid. Norwegian Shelf. Petroleum Geoscience 10, 353-365. https://doi.org/10.1144/1354-079303-616.

Robertson, E. 1988: Thermal properties of rocks. USGS Report 88-44, 110 pp. https://doi.org/10.3133/ofr88441

Rudlang, T. 2010: Determination of Heat Flow in Exploration Wells, North Sea. Project Assignment Petroleum Geology TGB4560, Norges teknisk-naturvitenskapelig universitet, Trondheim, 58 pp. 
Shat, M.L., Richardson, R.M., Flaccus, C. \& Engelder, T. 1984: Near-surface in situ stress strain relaxation measurements along the San Andreas fault in southern California. Journal of Geophysical Research 89, 9323-9332. https://doi.org/10.1029/JB089iB11p09323.

Shearer, P.M., Prieto, G.A. \& Hauksson, E. 2006: Comprehensive analysis of earthquake source spectra in southern California. Journal of Geophysical Research: Solid Earth 111, B06303.

https://doi.org/10.1029/2005JB003979.

Shipton, Z.K., Soden, A.M., Kirkpatrick, J.D., Bright, A. \& Lunn, R.T. 2006: How thick is a fault? Fault displacement - thickness scaling revisited. Earthquakes: radiated energy and the physics of faulting 170 , 193-198. https://doi.org/10.1029/170GM19.

Sibson, R.H. 1973: Interactions between temperature and fluid pressure during earthquake faulting A mechanism for partial or total stress relief. Nature 243, 66-68. https://doi.org/10.1038/ physci243066a0.

Sibson, R.H. 1977: Kinetic shear resistance, fluid pressures and radiation efficiency during seismic faulting. Pure and Applied Geophysics 115, 387-400. https://doi.org/10.1007/978-3-0348-5745-1_24.

Sibson, R.H. 2003: Thickness of the seismic slip zone. Bulletin of the Seismological Society of America 93, 1169-1178. https://doi.org/10.1785/0120020061.

Slagstad, T., Balling, N., Elvebakk, H., Midttømme, K., Olesen, O., Olsen, O. \& Pascal, C. 2009: Heat-flow measurements in Late Palaeoproterozoic to Permian geological provinces in south and central Norway and a new heat-flow map of Fennoscandia and the Norwegian-Greenland Sea. Tectonophysics 473, 341-361. https://doi.org/10.1016/j.tecto.2009.03.007.

Swanberg, C.A., Chessman, M.D., Simmons, G., Smithson, S.B., Grønlie, G. \& Heier, K.S. 1974. Heat flow - heat generation studies in Norway. Tectonophysics 23, 31-48.

https://doi.org/10.1016/0040-1951(74)90109-7.

Uslar, A., Ortiz, A, Estay, R., Pavez, C. \& Brönner, M. 2020: Simulation of frictional heat generation due to underground motion. European Geosciences Union Sharing Geosciences Online, 4-8 May, EGU202010795. https://doi.org/10.5194/egusphere-egu2020-10795.

Vassiliou, M.S. \& Kanamori, H. 1982: The energy release in earthquakes. Bulletin of the Seismological Society of America 72, 371-387.

Warren, N.W. \& Latham, G.V. 1970: An experimental study of thermally induced micro-fracturing and its relation to volcanic seismicity. Journal of Geophysical Research 75, 4455-4464. https://doi.org/10.1029/JB075i023p04455.

Wong, T. \& Brace, W.F. 1979: Thermal expansion of rocks: some measurements at high pressure. Tectonophysics 57, 95-117. https://doi.org/10.1016/0040-1951(79)90143-4.

Wulff, A.M. \& Burkhardt, H. 1996: The influence of local fluid flow and microstructure on elastic and anelastic rock properties. Surveys in Geophysics 17, 347-360. https://doi.org/10.1007/BF01904048. 